\title{
A Comparison of Respiratory Functions, Functional Capacity and Quality of Sleep in Patients with OSAS and COPD Compared to Healthy Controls
}

\section{OUAS'li ve KOAH'li Hastalarla Sağlıklı Kișiler Arasında Solunum Fonksiyonları, Fonksiyonel Kapasite ve Uyku Kalitesinin Karșılaștırılması}

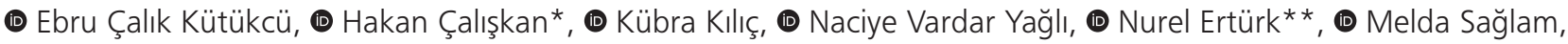

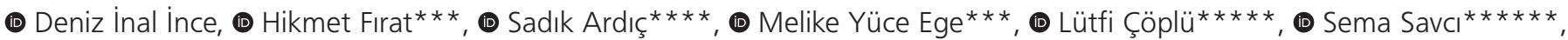 \\ (D) Hülya Arıkan******* \\ Hacettepe University Faculty of Physical Therapy and Rehabilitation, Ankara, Turkey \\ *The Ministry of Health Ankara Dışkapı Yıldırım Beyazıt Training and Research Hospital, Ankara, Turkey \\ **Ahi Evren University Faculty of Medicine, Thorax and Cardivascular Surgery Training and Research Hospital, Trabzon, Turkey \\ ***The Ministry of Health Ankara Dışkapı Yıldırım Beyazıt Training and Research Hospital, Department of Chest Diseases and Sleep Center, Ankara, Turkey \\ ****Koru Ankara Hospital, Ankara, Turkey \\ *****Hacettepe University Faculty of Medicine, Department of Chest Diseases, Ankara, Turkey \\ ******Dokuz Eylul University School of Physical Therapy and Rehabilitation, Izmir, Turkey \\ ******AtılIm University Faculty of Health Sciences, Department of Physiotherapy and Rehabilitation, Ankara, Turkey
}

\begin{abstract}
Objective: The purpose of this study was to compare the respiratory functions, exercise performance, and quality of sleep in patients with Obstructive Sleep Apnea syndrome (OSAS) and Chronic Obstructive Pulmonary disease (COPD) compared to healthy individuals.

Materials and Methods: Seventeen patients with OSAS (12 M, 5 F), 24 patients with COPD (20 M, 4 F) and 20 healthy subjects ( $15 \mathrm{M}$, 5 F) participated in this cross-sectional study. Respiratory function and muscle strength tests were performed. Knee extensors, shoulder abductors, and hand grip strength were measured in patients with OSAS and COPD using a digital hand-held dynamometer. Exercise performance was evaluated using a 6-minute walk test (6MWT), and sleep quality was assessed by the Pittsburgh Sleep Quality index (PSQI). Results: The 6MWT distance, 6MWT\% distance, actual and percentage values of shoulder abductors muscle strength of patients with COPD were significantly lower than those of the OSAS group $(p<0.05)$. According to PSQI recordings, $58.8 \%$ of OSAS patients' sleep quality, $58.3 \%$ COPD patients' sleep quality, and $15.0 \%$ of healthy individuals' sleep quality were poor $(p=0.006)$. The PSQI-sleep disturbance, daytime dysfunction, habitual sleep efficiency subdimensions, and total scores of PSQI in OSAS and COPD group were higher than those of healthy individuals $(p<0.05)$.

Conclusion: This study showed that sleep quality is adversely affected in both OSAS and COPD patients and sleep disturbance and daytime dysfunction increases and habitual sleep efficiency decreases in OSAS and COPD patients compared to those of healthy individuals.

Keywords: Obstructive sleep apnea, exercise test, muscle strength, respiratory muscles, Chronic Obstructive Pulmonary disease
\end{abstract}

Öz

Amaç: Bu çalışmanın amacı Obstrüktif Uyku Apne sendromu (OUAS) ve Kronik Obstrüktif Akciğer hastalığı (KOAH) olan hastalarda solunum fonksiyonları, egzersiz performansı ve uyku kalitesini sağlıkı bireylerle karşılaştırmaktır.

Gereç ve Yöntem: Bu kesitsel çalışmaya 17 OUAS'li hasta (12 erkek, 5 kadın), $24 \mathrm{KOAH}^{\prime} l i$ hasta (20 erkek, 4 kadın) ve 20 sağlıklı birey (15 erkek, 5 kadın) katıldı. Solunum fonksiyonu ve kas kuvvet testleri yapıldı. OUAS ve KOAH'li hastalarda diz ekstansörleri, omuz abduktörleri ve el kavrama kuvveti dijital el dinamometresi kullanılarak ölçüldü. Egzersiz performansı 6 dakika yürüme testi (6DYT) kullanılarak, uyku kalitesi Pittsburgh Uyku Kalitesi indeksi (PUKI) ile değerlendirildi.

Bulgular: KOAH'li hastaların 6DYT mesafesi, 6DYT mesafesi (\%), omuz abduktörleri kas kuvveti ölçülen ve yüzde değerleri OUAS grubuna göre anlamlı olarak düşüktü $(p<0,05)$. PUKI kayıtlarına göre OUAS hastalarının \%58,8'inin, KOAH hastalarının \%58,3'ünün ve sağ|ıklı bireylerin $\% 15,0^{\prime}$ inin uyku kalitesi zayıftı $(p=0,006)$. OUAS ve KOAH grubunda PUKI-uyku bozukluğu, gündüz fonksiyon bozukluğu, alışılmış uyku etkinliği alt boyutları ve toplam PUKI skorları sağlıklı bireylerden daha yüksekti $(p<0,05)$.

Sonuç: Bu çalışma, hem OUAS hem de KOAH hastalarında uyku kalitesinin olumsuz etkilendiğini ve sağlıklı bireylere göre OUAS ve $\mathrm{KOAH}$ hastalarında uyku bozukluğu ve gündüz fonksiyon bozukluğunun arttığını ve alışılmış uyku etkinliğinin azaldığını göstermiştir.

Anahtar Kelimeler: Obstrüktif uyku apnesi, egzersiz testi, kas kuvveti, solunum kasları, Kronik Obstrüktif Akciğer hastalığı 


\section{Introduction}

Chronic Obstructive Pulmonary disease (COPD) and Obstructive Sleep Apnea syndrome (OSAS) are two common Obstructive Respiratory diseases. The COPD is a systemic disorder that is resulting in persistent airflow limitation and respiratory symptoms (1). The OSAS is a disorder characterized by the repetitive complete or partial collapse of the upper airway during sleep (2). While many factors including edema, obesity, and genetics change the anatomy of upper airways, problems in neuromuscular function leading to a decrease in dilator muscle activity in sleep, respiratory control instability, and many anatomical risk factors play a direct role in the pathogenesis of OSAS $(2,3)$.

Regardless of whether the patients with OSAS have airway or parenchymal lung disease, lung volumes reduce, and this decline is related to OSAS severity (4). Otherwise, recurrent airway obstruction and the subsequent asphyxia can increase inspiratory efforts and leads to an increase in the incidence of inspiratory muscles fatigue $(5,6)$. OSAS has been shown as a systemic oxidative disorder (7). Oxidative stress was shown to be an essential role in peripheral muscle dysfunction in patients with COPD (8). In an investigation with severe OSAS, both peripheral and inspiratory muscle strength were reduced, and inspiratory muscle fatigue was increased compared to healthy controls (6).

The maximal exercise capacity was demonstrated to be declined in patients with OSAS compared to healthy counterparts, and this reduction is associated with disease severity determined by Apnea-Hypopnea index (AHI) (9). Another study showed that the OSAS patients walked shorter than lean, healthy controls in 6-minute walk test (6MWT) (10).

Almost $70 \%$ of the patients with COPD have reduced quality of sleep (11). Otherwise, it was shown that patients with OSAS had more respiratory disturbances during sleep and excessive sleepiness than COPD patients (12). Although there are clinical studies that compare the clinical findings between COPD and OSAS patients (13), also in the COPD-OSAS Overlap syndrome (14), there is a limited data that evaluates lung functions, respiratory muscle strength and sleep quality changes between these Obstructive diseases and compares healthy controls as a reference point. The comparison of OSAS and COPD as two obstructive diseases will provide an understanding of the effect of OSAS on patients in terms of respiratory parameters and muscle function with respect to COPD patients and guide the establishment of optimal treatment programs in rehabilitation programs. Therefore, the purpose of this study was to compare the respiratory functions, exercise performance, and quality of sleep in patients with OSAS and COPD compared to healthy individuals.

\section{Materials and Methods}

\section{Participants}

The study was conducted at Hacettepe University Faculty of Physical Therapy and Rehabilitation, Cardiopulmonary Rehabilitation Unit. This cross-sectional study included 17 patients with OSAS (12 M, 5 F), 24 patients with COPD (20 $\mathrm{M}, 4 \mathrm{~F}$ ) and 20 healthy subjects (15 M, $5 \mathrm{~F}$ ) aged 30-80 years old. Patients who could be cooperative for evaluations and can have walking ability and stable health status (patients who have not had an acute exacerbation last three months for the COPD group) included in the study. Patients with a neurological, cardiovascular, orthopedic, endocrine, or psychological disease that may affect outcomes, and patients with Body Mass index (BMI) $40 \mathrm{~kg} / \mathrm{m}^{2}$ or more were excluded. All OSAS patients were newly diagnosed and were not receiving CPAP-therapy. The healthy group was composed of individuals among the relatives of researchers and academic personnel that were without known systemic, orthopedic or neurologic diseases, cooperative and voluntary to participate to study. It was confirmed by pulmonary function tests that the healthy group has no COPD diagnosis. The Hacettepe University Ethics Committee has approved the study (number: GO 18/491). Participants were informed about the trial, and their written informed consents were collected before the study.

\section{Assessments}

Physical data (age, height, weight) were recorded. BMI was calculated as body weight/height ${ }^{2}\left(\mathrm{~kg} / \mathrm{m}^{2}\right)$. BMI was classified like underweight $\left(<18.5 \mathrm{~kg} / \mathrm{m}^{2}\right)$, normal $\left(18.5-24.99 \mathrm{~kg} / \mathrm{m}^{2}\right)$, overweight $\left(>25 \mathrm{~kg} / \mathrm{m}^{2}\right)$ and obese $\left(>30 \mathrm{~kg} / \mathrm{m}^{2}\right)$ (15). Dyspnea during effort, cough, and sputum symptoms were recorded in all three groups.

Polysomnography findings were recorded for the OSAS patients. The term AHI was described as the number of apnoeas plus hypopnoea per hour of sleep. According to their AHI scores, the OSAS patients were described as like: mild OSAS (AHI $<15 / \mathrm{hr}$ ), moderate OSAS (AHI between 15 and 30/hr), and severe OSAS (AHI $\geq 30 / h r)$ (16).

Pulmonary function test was performed in all groups using a Spirolab III spirometer (Spirolab, Medical International Research, Rome, Italy) in the sitting position. Pulmonary function test results were expressed as the actual values ( $L$ ) and the percentages of the expected values adjusted for age, height, body weight, and sex (17). Airflow limitation severity was classified as mild (Global Inıtiative Obstructive Lung diseases (GOLD) stage I) if $\mathrm{FEV}_{1} \geq 80 \%$ predicted, moderate (GOLD stage II) if $50 \% \leq \mathrm{FEV}_{1}<80 \%$ predicted, severe (GOLD stage III) if $30 \% \leq \mathrm{FEV}_{1}<50 \%$ predicted and very severe (GOLD stage IV) if $\mathrm{FEV}_{1}<30 \%$ predicted (1).

Respiratory muscle strength was determined by measuring maximal inspiratory pressure (MIP), and maximal expiratory pressure (MEP) generated at the mouth using a mouth pressure device (MicroRPM, Micromedical, Kent, United Kingdom) (18). The respiratory muscle strength results were expressed as actual values and percentages of normal values that are calculated using regression equations according to age and sex (19).

Peripheral muscle strength (knee extensors, shoulder abductors, and hand grip strength) was measured in patients with OSAS and COPD using a digital hand-held dynamometer (JTECH, Medical Commander Powertrack II, USA). Peripheral muscle strength testing was repeated three times for each muscle. The best value of the dominant sides in Newtons $(N)$ was then 
taken for statistical analysis (20). The peripheral muscle strength results were expressed as actual values and percentages of the expected values adjusted for age and sex $(21,22)$. The peripheral muscle strength assesment was not applied to healthy controls because this measurement have reference values according to age and gender and results were expressed as percentages of this expected values.

The 6MWT is a self-paced test of walking capacity. Patients were requested to walk as far as possible in 6 min along a flat corridor. Standardized instructions and encouragement are commonly given during the test. The test was administered twice in the same day with a half-hour interval. The distance in meters is recorded, and the best value was taken for the analysis. The 6MWT distance was expressed as percentages of the expected values from age and sex (6MWT\% of distance) (23).

The Pittsburgh Sleep Quality index (PSQI) is a self-rating questionnaire that evaluates the quality of sleep and consists of seven subscores (sleep quality, sleep latency, sleep duration, habitual sleep efficiency, sleep disturbance, use of sleep medication, and daytime dysfunction), and global score ranges between 0 and 21. A PSQI total score higher than 5 indicates poor sleep quality (24).

\section{Statistical Analysis}

All analyses were performed using the Statistical Package for the Social Sciences (version 18.0) for Windows (Version
18.0, IBM Inc., Armonk, NY, USA) (25). For categorical variables, frequencies and percentages were presented, and for continuous variables, the mean and standard deviation were given. The variables were investigated to determine whether or not they were normally distributed using visual (histograms/ probability plots) and Kolmogorov-Smirnov test, as appropriate. According to the normality of a variable, One-Way ANOVA or Kruskal-Wallis tests were used to compare variables between the groups. Levene's test was used to assess the homogeneity of the variances. An overall 5\% type-1 error level was used to infer statistical significance. When an overall significance observed, pairwise post-hoc tests performed using Tukey's test or Tamhane's $\mathrm{T}^{2}$ test. For Kruskal-Wallis test, the Mann-Whitney $\mathrm{U}$ test was performed to test the significance of pairwise differences using Bonferroni correction to adjust for multiple corrections (26). To calculate clinically essential differences between groups using 6MWT distance values as the primary outcome measure, with $80 \%$ statistical power and an alpha of 0.05 , nine patients had to be included in each group.

\section{Results}

Data regarding the characteristics of patients and healthy individuals are shown in Table 1. Age, height, weight and BMI values, and gender distribution were comparable between groups ( $p>0.05$, Table 1). According to BMI classification, 5.9\% of patients with OSAS were normal, $52.9 \%$ of patients with

\begin{tabular}{|c|c|c|c|c|}
\hline \multirow[t]{2}{*}{ Variables } & \multirow{2}{*}{\begin{tabular}{|l|}
$\begin{array}{l}\text { OSAS } \\
(n=17)\end{array}$ \\
Mean (SD) \\
\end{tabular}} & \multirow{2}{*}{$\begin{array}{l}\text { COPD } \\
(\mathrm{n}=24) \\
\text { Mean (SD) }\end{array}$} & \multirow{2}{*}{\begin{tabular}{|l|l}
$\begin{array}{l}\text { Healthy } \\
(\mathrm{n}=20)\end{array}$ \\
Mean (SD) \\
\end{tabular}} & \multirow{2}{*}{$p$} \\
\hline & & & & \\
\hline Age (years) & $55.06 \pm 4.66$ & $57.20 \pm 7.10$ & $79.94 \pm 10.81$ & 0.166 \\
\hline Body weight (kg) & $79.94 \pm 10.81$ & $76.48 \pm 15.46$ & $75.00 \pm 9.48$ & 0.479 \\
\hline Height $(\mathrm{cm})$ & $166.12 \pm 9.46$ & $168.33 \pm 6.73$ & $167.60 \pm 6.55$ & 0.649 \\
\hline BMI $\left(\mathrm{kg} / \mathrm{m}^{2}\right)$ & $28.99 \pm 3.29$ & $26.87 \pm 4.41$ & $26.62 \pm 2.38$ & 0.093 \\
\hline Gender (Male/Female) & $12 / 5$ & $20 / 4$ & $15 / 5$ & 0.611 \\
\hline $\mathrm{FEV}_{1}(\mathrm{~L})$ & $3.16 \pm 0.80$ & $1.60 \pm 0.74$ & $2.98 \pm 0.49$ & 0.089 \\
\hline FVC (L) & $3.59 \pm 0.85$ & $2.61 \pm 0.85$ & $3.75 \pm 0.53$ & $<0.001^{*}$ \\
\hline $\mathrm{FEV}_{1}(\%)$ & $106.35 \pm 14.95$ & $49.46 \pm 18.60$ & $102.85 \pm 11.78$ & $<0.001^{\&}$ \\
\hline FVC (\%) & $98.45 \pm 13.47$ & $66.92 \pm 17.31$ & $104.20 \pm 8.43$ & $<0.001^{*}$ \\
\hline $\mathrm{FEV}_{1} / \mathrm{FVC}(\%)$ & $87.66 \pm 5.62$ & $60.10 \pm 12.60$ & \begin{tabular}{|l|}
$79.94 \pm 7.94$ \\
\end{tabular} & $<0.001^{\&}$ \\
\hline $\mathrm{FEF}_{25-75 \%}(\mathrm{~L})$ & $3.77 \pm 1.60$ & $1.12 \pm 0.82$ & $2.96 \pm 1.04$ & $<0.001^{*}$ \\
\hline $\mathrm{FEF}_{25-75 \%}(\%)$ & $106.75 \pm 39.45$ & $26.92 \pm 14.32$ & $89.90 \pm 30.16$ & $<0.001^{*}$ \\
\hline $\operatorname{PEF}(\mathrm{L})$ & $7.83 \pm 2.24$ & $4.72 \pm 2.00$ & $6.99 \pm 2.13$ & $<0.001^{*}$ \\
\hline PEF (\%) & $101.49 \pm 20.92$ & $56.20 \pm 23.04$ & $95.90 \pm 21.17$ & $<0.001^{*}$ \\
\hline $\operatorname{MIP}\left(\mathrm{cmH}_{2} \mathrm{O}\right)$ & $107.29 \pm 33.29$ & $94.30 \pm 24.59$ & $96.55 \pm 15.85$ & 0.280 \\
\hline MIP \% & $105.37 \pm 31.32$ & $91.14 \pm 23.55$ & $99.03 \pm 22.15$ & 0.172 \\
\hline $\operatorname{MEP}\left(\mathrm{cmH}_{2} \mathrm{O}\right)$ & $144.35 \pm 39.67$ & $143.68 \pm 33.42$ & $121.90 \pm 29.84$ & 0.089 \\
\hline MEP \% & $72.60 \pm 17.97$ & $69.52 \pm 15.46$ & $62.04 \pm 11.52$ & 0.083 \\
\hline
\end{tabular}


OSAS were overweight, and $41.2 \%$ of patients with OSAS were obese. The $4.2 \%$ of COPD patients were cachectic, $29.2 \%$ of COPD patients were normal, $37.5 \%$ of COPD patients were overweight, and $29.2 \%$ of COPD patients were obese. The $25 \%$ of healthy individuals were normal, $60 \%$ of healthy individuals were overweight, and $15 \%$ of healthy individuals were obese. There was not a significant difference between groups concerning BMl classifications $(p=0.611)$. The $52.9 \%$ of the OSAS patients had exertional dyspnea, 5.9\% had a cough, and $23.5 \%$ patients had sputum symptoms. Seventy-nine point three percentage of COPD patients had exertional dyspnea, $46.3 \%$ had cough, and $53.7 \%$ had sputum symptoms. Thirtyfive percentage of healthy individuals had exertional dyspnea, $10 \%$ of healthy individuals had a cough, and $5 \%$ of healthy individuals had sputum symptoms.

There were significant differences in all parameters of respiratory function test between the groups $(p<0.05$, Table 1$)$. The FEV (L), $\mathrm{FEV}_{1}(\%), \mathrm{FVC}(\mathrm{L}), \mathrm{FVC}(\%), \mathrm{FEF}_{25-75 \%}(\mathrm{~L}), \mathrm{FEF}_{25-75 \%}(\%), \mathrm{PEF}$ (L), and PEF (\%) values of patients with COPD were significantly lower than those of the OSAS group and healthy group $\left(p<0.017\right.$, Table 1). The $\mathrm{FEV}_{1} / \mathrm{FVC}(\%)$ of patients with COPD was significantly lower than those of the OSAS and healthy groups, but The $\mathrm{FEV}_{1} / \mathrm{FVC}$ (\%) of OSAS group was significantly higher than healthy group ( $<<0.017$, Table 1$)$. According to spirometry results, $4.2 \%$ of COPD patients in the GOLD stage I, $50 \%$ of COPD patients in the GOLD stage II, $25 \%$ of COPD patients in the GOLD stage III and $20.8 \%$ of COPD patients in the GOLD stage IV (27). Mean AHI values of OSAS patients were $32.02 \pm 19.88$. Five patients $(29.4 \%)$ were in the mild OSAS group, four patients $(23.5 \%)$ were in the moderate OSAS group, and eight patients (47.1\%) were in severe OSAS group. According to respiratory muscle strength measurements, there was not a statistically significant difference in MIP, MEP, \%MIP, and \%MEP values between three groups ( $p>0.05$, Table 2 ). When we analyze the peripheral muscle strength measurements, the shoulder abductors muscle strength (Figure 1) and percentage of shoulder abductors muscle strength according to normative values of COPD patients were significantly lower than those of OSAS patients ( $p<0.05$, Table 2$)$. There was not any significant difference in other peripheral muscle strength measurements between two groups ( $p>0.05$, Table 2 ).

There were a statistically significant difference in 6MWT distance (Figure 2) and 6MWT\% distance between three groups $(\mathrm{p}<0.05$, Table 2$)$. The $6 \mathrm{MWT}$ distance and $6 \mathrm{MWT} \%$ distance of patients with COPD were significantly lower than those of the OSAS group $(p<0.017$, Table 2$)$. The percentage of maximal heart rate (HR) reached during 6MWT in patients with OSAS was significantly lower than those of COPD patients and healthy individuals $(p<0.017$, Table 2$)$. There were statistically significant differences in changes in $\mathrm{HR}, \mathrm{SpO}_{2}$, perceptions of dyspnea, leg fatigue, and general fatigue during $6 \mathrm{MWT}$ among the groups ( $p<0.05$, Table 2$)$. The HR increase during 6MWT was higher in COPD and healthy groups than OSAS group $\left(\mathrm{p}<0.05\right.$, Table 2). The decrease in $\mathrm{SpO}_{2}$ during 6MWT was higher in the COPD group than OSAS group $(p<0.05$, Table
2). The increases in dyspnea, leg fatigue, and general fatigue perceptions during 6MWT were higher in COPD patients than those in OSAS patients $(p<0.05$, Table 2$)$. In addition, the increases in dyspnea and general fatigue perceptions during 6MWT were higher in COPD patients than those of healthy subjects ( $p<0.05$, Table 2 ).

According to PSQI recordings, $58.8 \%$ of OSAS patients' sleep quality, $58.3 \%$ COPD patients' sleep quality, and $15.0 \%$ of healthy individuals' sleep quality were poor $(p=0.006)$. There were statistically significant differences in sleep duration, sleep disturbance, daytime dysfunction, habitual sleep efficiency subdimensions, and total scores of PSQI among the three groups ( $p<0.05$, Table 2, Figure 3). The PSQI-sleep duration score of OSAS patients was significantly lower than COPD patients and healthy individuals ( $p<0.017$, Table 2 ). The PSQIsleep duration score of COPD patients was significantly higher than healthy individuals $(p<0.017$, Table 2$)$. The PSQI-sleep disturbance, daytime dysfunction, habitual sleep efficiency subdimensions, and total scores of PSQI in OSAS and COPD group were higher than those of healthy individuals $(p<0.017$, Table 2).

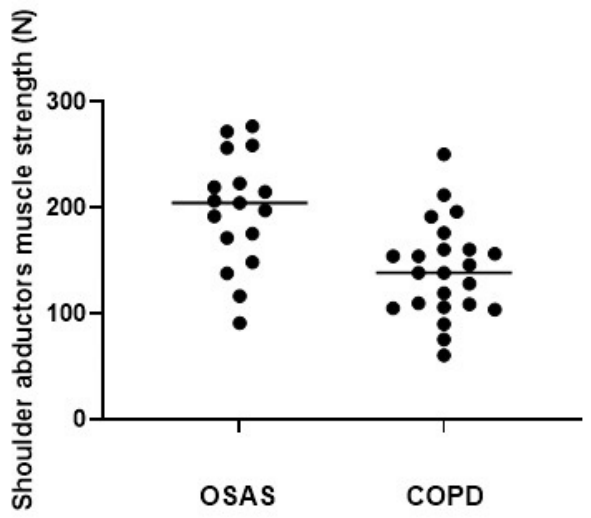

Figure 1. The comparison of shoulder abductors muscle strength between patients with Obstructive Sleep Apnea syndrome and patients with Chronic Obstructive Pulmonary disease

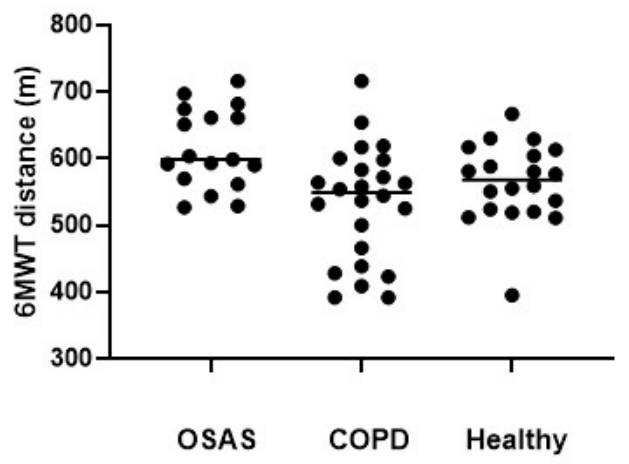

Figure 2. The comparison of 6MWT distance between patients with Obstructive Sleep Apnea syndrome, patients with Chronic Obstructive Pulmonary disease and healthy controls 
Çalık Kütükcü et al.

Functional Capacity and Quality of Sleep in Patients with OSAS and COPD Compared to Healthy Controls

\begin{tabular}{|c|c|c|c|c|c|c|c|}
\hline Variables & $\begin{array}{l}\text { OSAS } \\
(n=17)\end{array}$ & $\begin{array}{l}\text { COPD } \\
(n=24)\end{array}$ & \begin{tabular}{|l|} 
Healthy \\
$(n=20)$
\end{tabular} & & $\begin{array}{l}\text { OSAS vs } \\
\text { COPD }\end{array}$ & $\begin{array}{l}\text { COPD vs } \\
\text { healthy }\end{array}$ & $\begin{array}{l}\text { OSAS vs } \\
\text { healthy }\end{array}$ \\
\hline & Mean (SD) & Mean (SD) & Mean (SD) & $\mathbf{p}$ & $p$ & p & $p$ \\
\hline $\begin{array}{l}\text { Shoulder abductors } \\
\text { muscle strength (N) }\end{array}$ & $201.41 \pm 55.10$ & $136.33 \pm 47.90$ & & $<0.001^{*}$ & & & \\
\hline $\begin{array}{l}\text { Shoulder abductors } \\
\text { muscle strength \% }\end{array}$ & $98.69 \pm 23.96$ & $67.29 \pm 19.44$ & & $<0.001^{*}$ & & & \\
\hline Handgrip strength $(\mathrm{N})$ & $219.81 \pm 82.42$ & $191.81 \pm 53.10$ & & 0.230 & & & \\
\hline Handgrip strength $\%$ & $55.46 \pm 22.17$ & $46.09 \pm 11.79$ & & 0.153 & & & \\
\hline $\begin{array}{l}\text { Knee extensors } \\
\text { muscle strength }(\mathrm{N})\end{array}$ & $354.70 \pm 115.58$ & $309.92 \pm 68.40$ & & 0.167 & & & \\
\hline $\begin{array}{l}\text { Knee extensors } \\
\text { muscle strength \% }\end{array}$ & $80.36 \pm 18.80$ & $74.02 \pm 14.52$ & & 0.236 & & & \\
\hline 6MWT distance $(\mathrm{m})$ & $614.69 \pm 60.02$ & $532.70 \pm 86.28$ & $563.43 \pm 59.80$ & $0.008^{\&}$ & $0.002^{\beta}$ & & \\
\hline Maximum HR \% & $48.40 \pm 6.19$ & $73.16 \pm 12.66$ & $69.58 \pm 7.94$ & $<0.001^{\&}$ & $<0.001^{\circ}$ & & $<0.001^{\circ}$ \\
\hline \multirow[t]{2}{*}{$\Delta \mathrm{HR}$ (beats/min) } & $3.23 \pm 11.13$ & $35.08 \pm 18.68$ & $36.80 \pm 12.15$ & $<0.001^{\&}$ & $<0.001^{\beta}$ & & $<0.001^{\beta}$ \\
\hline & Median (min-max) & Median (min-max) & Median (min-max) & & & & \\
\hline 6MWT \% & $\begin{array}{l}112.26 \\
(101.29-142.35) \\
\end{array}$ & $\begin{array}{l}101.22 \\
(69.97-121.58)\end{array}$ & $\begin{array}{l}108.25 \\
(80.28-125.39) \\
\end{array}$ & $0.002^{\varnothing}$ & $0.001^{\mu}$ & & \\
\hline$\Delta \mathrm{SpO}_{2}(\%)$ & $0.59(-5-5)$ & $-3.21(-20-2)$ & $-0.45(-3-4)$ & $0.002^{\varnothing}$ & $0.001^{\mu}$ & & \\
\hline$\Delta$ Dyspnea (modified Borg) & $-0.41(-5-0)$ & $2.13(0-7)$ & $0.38(0-3)$ & $<0.001^{\varnothing}$ & $<0.001^{\mu}$ & $0.001^{\mu}$ & \\
\hline$\Delta$ Leg Fatigue (modified Borg) & $-0.35(-3-1)$ & $-0.7(-2-4)$ & $0.53(0-3)$ & $0.012^{\varnothing}$ & $0.016^{\mu}$ & & $0.011^{\mu}$ \\
\hline $\begin{array}{l}\Delta \text { General Fatigue } \\
\text { (modified Borg) }\end{array}$ & $-0.47(-6-3)$ & $1.63(-2-6)$ & $0.53(0-2.5)$ & $0.009^{\varnothing}$ & $0.014^{\mu}$ & $0.009^{\mu}$ & \\
\hline PSQI-sleep duration score & $0(0-3)$ & $1(0-2)$ & $0.5(0-2)$ & $0.009^{\varnothing}$ & $0.015^{\mu}$ & $0.005^{\mu}$ & \\
\hline PSQI-sleep disturbance score & $2(1-3)$ & $1(0-2)$ & $1(0-2)$ & $<0.001^{\varnothing}$ & & $0.004^{\mu}$ & $<0.001^{\mu}$ \\
\hline PSQI-sleep latency score & $1(0-3)$ & $1(0-2)$ & $0(0-4)$ & 0.061 & & & \\
\hline PSQI-daytime dysfunction score & $1(0-3)$ & $1(0-2)$ & $0(0-2)$ & $<0.001^{\varnothing}$ & & $<0.001^{\mu}$ & $0.014^{\mu}$ \\
\hline $\begin{array}{l}\text { PSQI-habitual sleep } \\
\text { efficiency score }\end{array}$ & $0(0-3)$ & $1(0-2)$ & $0(0-0)$ & $<0.001^{\varnothing}$ & & $<0.001^{\mu}$ & \\
\hline PSQI-sleep quality score & $1(0-3)$ & $1(0-2)$ & $1(0-2)$ & 0.133 & & & \\
\hline $\begin{array}{l}\text { PSQI-use of sleep } \\
\text { medication score }\end{array}$ & $0(0-0)$ & $0(0-1)$ & $0(0-0)$ & 0.463 & & & \\
\hline PSQI-total score (0-21) & $6.35(1-14)$ & $6.13(1-10)$ & $2.95(0-9)$ & $<0.001^{\varnothing}$ & & $<0.001^{\mu}$ & $0.002^{\mu}$ \\
\hline
\end{tabular}

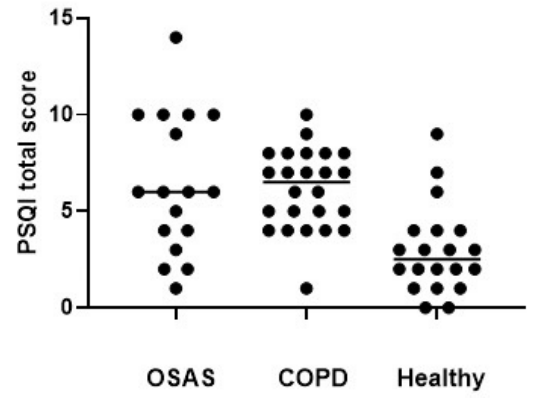

Figure 3. The comparison of PSQI total score between patients with Obstructive Sleep Apnea syndrome, patients with chronic obstructive pulmonary disease and healthy controls

\section{Discussion}

The main findings of our study are that pulmonary functions, peripheral muscle strength, and functional exercise capacity are more negatively affected in patients with COPD than patients with OSAS. Otherwise, pulmonary functions, respiratory muscle strength, and exercise capacity are preserved in OSAS patients compared to healthy counterparts. Although the worst sleep quality is seen in patients with OSAS, sleep disturbance, daytime dysfunction, habitual sleep efficiency, and global sleep quality are worse in both OSAS and COPD groups compared to those of healthy individuals.

There is an inconsistency about the data about the association between lung volume and OSAS severity is independent of 
obesity (4). Some findings support lower lung volumes in OSAS compared to BMI-matched healthy controls $(6,28)$. Oztürk et al. (29) found that OSAS patients (mean AHI $44 \pm 19)$ and healthy controls had similar pulmonary function characteristics and judged that extrathoracic airway obstruction might be a presence in only severe OSAS. The lower spirometry measurement recordings in COPD than patients with OSAS and healthy subjects was consistent with the literature and an expected finding $(13,30)$. We think that similar pulmonary function results between OSAS and healthy groups are related to that only $42 \%$ of OSAS patients was obese, and the group included OSAS patients from every disease stages.

Existing data suggest that there is a modest relationship between airway obstruction and muscle dysfunction in COPD (31), and muscle weakness does not affect all muscle groups at the same level (32). Otherwise, muscle abnormalities may have been observed in the early stages of disease (31). Just the opposite, inspiratory muscle strength may not be reduced compared to healthy controls when corrected for lung volume in COPD (33). In a trial with 15 severe OSAS (mean AHI: $54.0 \pm 21.7$ ), muscle strength and endurance of inspiratory and knee extensors were shown to be reduced than BMI-matched healthy counterparts (6). In our study, the similar inspiratory, expiratory, knee extensors and handgrip strength between three groups can be related to COPD and OSAS patients consisted patients from all stages. Lower shoulder abductors muscle strength in COPD patients than healthy controls is consistent with previous findings that consist mostly of GOLD stage II-III patients (30). The explanation for this finding may be that COPD patients can reduce unsupported arm movements in order to avoid dyspnea. The preservation in quadriceps muscle strength can be explained with lack of deconditioning because both COPD and OSAS patients' exercise capacity had reached up higher than $100 \%$ of the expected values.

Ilgin et al. (13) have shown that exercise capacity levels in patients with COPD and OSAS who had similar obstruction level were comparable. In addition, there was a correlation between 6MWT distance and disease severity by $\mathrm{AHI}, \mathrm{FEV}_{1}$, FVC, and an increase in dyspnea perception and hemodynamic parameters during exercise in OSAS. In the COPD group, only there was a correlation between 6MWT and FEV 1 and FVC. The maximal exercise capacity by the incremental shuttle walk test (ISWT) distance was strongly associated with $\mathrm{FEV}_{1}$ and FVC in moderate-to-severe OSAS (34). Although disease severities were similar between COPD and OSAS patients in our study, lower airway obstruction level in COPD patients can be related with lower functional exercise capacity, higher deoxygenation, increase in dyspnea, leg fatigue, and general fatigue perceptions during exercise, and it is consistent with our previous findings (30). The comparable exercise capacity between OSAS and healthy groups in our study can be related with that pulmonary functions of OSAS group were in the normal range, and most of the patients were not obese and severe OSAS $(34,35)$.

In our previous study in 2015, we found that $57 \%$ of the COPD patients had poor sleep quality (36). Ali Zohal et al.
(37) showed that $67.9 \%$ of mild-severe COPD patients had poor sleep quality, and they demonstrated worse sleep quality and more daytime sleepiness than the control group. Akinci et al. (38) demonstrated in their study involving 51 moderate to very severe COPD that patients were suffering from poor sleep quality (94\%) irrespective of OSAS. In another trial, the OSAS patients (mean $\mathrm{FEV}_{1}=77.70 \pm 7.71 \%$ ) was shown to have more respiratory disturbances during sleep and longer non-rapid eye movement sleep than patients with COPD (mean $\mathrm{FEV}_{1}=57.10 \pm 13.90 \%$ ) (12). Supporting the literature, our findings showed that OSAS and COPD groups had poor sleep quality compared to healthy controls. The most affected areas were sleep disturbance (to often go to the toilet at night, unable to breathe comfortably, delay to start of sleep, coughing and so on), daytime dysfunction like being hard to stay awake and reduced sleep efficiency in OSAS and COPD group. This supports the evidence that sleep quality is negatively affected in patients with OSAS and COPD because of dyspnea, nocturnal cough, effects of some medications, nocturnal hypoxemia, and so on (36-39). Lower sleep duration in OSAS and higher sleep duration score in COPD compared to healthy individuals supported the literature $(37,39)$.

\section{Study Limitations}

There are several limitations to this study. First of all, we could not have evaluated the exercise capacity with a cardiopulmonary exercise test as a gold standard that shows the underlying mechanisms that limit the exercise. Another limitation of our study, we did not evaluate respiratory muscle endurance that may be more adversely affected than respiratory muscle strength in patients with OSAS. In addition, because 6MWT is a self-paced walking test, OSAS patients in our study had reached almost $50 \%$ of maximal heart rate. This showed us that they could not have performed the best they could.

\section{Conclusion}

The present study demonstrated that the strength of peripheral muscles and exercise performance are adversely affected in patients with COPD than OSAS. Pulmonary functions, respiratory muscle strength, and exercise capacity are preserved in the OSAS group that mostly contain mild-moderate patients. Sleep quality is adversely affected in both OSAS and COPD patients and sleeps disturbance, and daytime dysfunction increases and habitual sleep efficiency decreases in OSAS and COPD patients compared to those of healthy individuals. Consequently, we can suggest that the presence of sleep disorders and evaluation of sleep quality should be considered in patients with COPD and must be one of the main components of assessments in clinical settings. Otherwise, although respiratory muscle strength and exercise capacity can be preserved in the early stages of OSAS, handgrip strength as a indicative for general muscle strength was under the predicted values. These supports the idea that peripheral muscle strength should be evaluated and improved in rehabilitation programs of OSAS from the beginning of the disease. 
Acknowledgments: The authors would like to thank the volunteer participants for their aids in the data collection process.

\section{Ethics}

Ethics Committee Approval: This study has been approved by the Ethics Committee of Non-interventional Research in Hacettepe University (21.06.2018; GO 18/491).

Informed Consent: Participants were informed about the study and their written informed consents were collected prior to study.

Peer-review: Externally and internally peer-reviewed.

\section{Author Contributions}

Concept: N.E., H.A., H.Ç., S.A., H.F., L.Ç., Design: H.A., N.V.Y., D.I.I.., E.Ç.K., Design: D.İ.I., H.F., M.S., N.V.Y., Data Collection or Processing: H.Ç., N.E., K.K., E.Ç.K., M.S., N.V.Y., S.S., M.Y.E., Analysis or Interpretation: E.Ç.K., K.K., Literature Search: E.Ç.K., M.S., N.V.Y., K.K., Writing: E.Ç.K., K.K., D.I.I.

Conflict of Interest: No conflict of interest was declared by the authors.

Financial Disclosure: The authors declared that this study received no financial support.

\section{References}

1. Singh D, Agusti A, Anzueto A, Barnes PJ, Bourbeau J, Celli BR, et al. Global strategy for the diagnosis, management, and prevention of chronic obstructive pulmonary disease: the GOLD Science Committee Report 2019. Eur Respir J 2019;53:1900164.

2. Chan AS, Phillips CL, Cistulli PA. Obstructive sleep apnoea--an update. Intern Med I 2010;40:102-6.

3. Kilinc O, Bayram H, editors. Türk Toraks Derneği Obstrüktif Uyku Apne Sendromu Tanı ve Tedavi Uzlaşı Raporu. Istanbul, Aves Yayıncilık, 2012.

4. Bikov A, Losonczy G, Kunos L. Role of lung volume and airway inflammation in obstructive sleep apnea. Respir Investig 2017;55:326-33.

5. Wilcox PG, Pare PD, Road JD, Fleetham JA. Respiratory muscle function during obstructive sleep apnea. Am Rev Respir Dis 1990;142:533-9.

6. Chien MY, Wu YT, Lee PL, Chang YJ, Yang PC. Inspiratory muscle dysfunction in patients with severe obstructive sleep apnoea. Eur Respir J 2010;35:373-80.

7. Lavie L. Obstructive sleep apnea syndrome: an oxidative stress disorder. Sleep Med Rev 2003;7:35-51.

8. Couillard A, Maltais F, Saey D, Debigaré R, Michaud A, Koechlin C LeBlanc P, Préfaut C. Exercise-induced quadriceps oxidative stress and peripheral muscle dysfunction in patients with chronic obstructive pulmonary disease. Am J Respir Crit Care Med 2003;167:1664-9.

9. Beitler JR, Awad KM, Bakker JP, Edwards BA, DeYoung P, Djonlagic I, Forman DE, Quan SF, Malhotra A. Obstructive sleep apnea is associated with impaired exercise capacity: a cross-sectional study. J Clin Sleep Med 2014;10:1199-204.

10. Alameri H, Al-Kabab Y, BaHammam A. Submaximal exercise in patients with severe obstructive sleep apnea. Sleep Breath 2010;14:145-51.

11. Nunes DM, Mota RM, de Pontes Neto OL, Pereira ED, de Bruin VM, de Bruin PF. Impaired sleep reduces quality of life in chronic obstructive pulmonary disease. Lung 2009;187:159-63.

12. Roehrs T, Merrion M, Pedrosi B, Stepanski E, Zorick F, Roth T. Neuropsychological function in obstructive sleep apnea syndrome (OSAS) compared to chronic obstructive pulmonary disease (COPD). Sleep 1995;18:382-8.
13. Ilgın D, Kul Karaali H, Ozalevli S, İtil O, Uçan ES. Comparison of exercise capacity in chronic obstructive pulmonary disease and obstructive sleep apnea syndrome. Turk Thorac J 2010;11:66-70.

14. Marin JM, Soriano JB, Carrizo SI, Boldova A, Celli BR. Outcomes in patients with chronic obstructive pulmonary disease and obstructive sleep apnea: the overlap syndrome. Am J Respir Crit Care Med 2010;182:325-31.

15. WHO Expert Consultation. Appropriate body-mass index for Asian populations and its implications for policy and intervention strategies. Lancet 2004;363:157-63.

16. Iber C, Israel SAS, Chesson A, Quan SF. The AASM manual for the scoring of sleep and associated events: rules, terminology and technical specifications. Westchester IL: American Academy of Sleep Medicine, 2007.

17. Culver BH, Graham BL, Coates AL, Wanger J, Berry CE, Clarke PK, Hallstrand TS, Hankinson JL, Kaminsky DA, MacIntyre NR, McCormack MC, Rosenfeld M, Stanojevic S, Weiner D]; ATS Committee on Proficiency Standards for Pulmonary Function Laboratories. Recommendations for a standardized pulmonary function report. An official American Thoracic Society Technical Statement. Am J Respir Crit Care Med 2017;196:1463-72.

18. Troosters T, Gosselink R, Decramer M. Respiratory muscle assessment. Eur Respir Mon 2005;31: 57-71.

19. Black LF, Hyatt RE. Maximal respiratory pressures: normal values and relationship to age and sex. Am Rev Respir Dis 1969;99:696-702.

20. Adams GM. Exercise physiology laboratory manual. Dubuque (IA), USA, Wm C Brown Publishers, 1990.

21. Mathiowetz V, Kashman N, Volland G, Weber K, Dowe M, Rogers S. Grip and pinch strength: normative data for adults. Arch Phys Med Rehabil 1985;66:69-74.

22. Bohannon RW. Reference values for extremity muscle strength obtained by hand-held dynamometry from adults aged 20 to 79 years. Arch Phys Med Rehab 1997;78:26-32.

23. Singh SJ, Puhan MA, Andrianopoulos V, Hernandes NA, Mitchell KE, Hill Cl, Lee AL, Camillo CA, Troosters T, Spruit MA, Carlin BW, Wanger J, Pepin V, Saey D, Pitta F, Kaminsky DA, McCormack MC, Maclntyre N, Culver BH, Sciurba FC, Revill SM, Delafosse V, Holland AE. An official systematic review of the European Respiratory Society/ American Thoracic Society: measurement properties of field walking tests in chronic respiratory disease. Eur Respir J 2014;44:1447-78.

24. Yucel Agargun $M$, Kara $H$, Anlar $O$. The validity and reliability of the Pittsburgh Sleep Quality Index. Turk Psikiyatr Dergisi 1996:7.

25. Green SB, Salkind NJ. Using SPSS for Windows and Macintosh: Analyzing and Understanding Data. United States of America: Pearson, 2013.

26. Hayran M, Hayran M. Sağlık Araştırmaları Için Temel İstatistik. Ankara, Omega Yayınları, 2011.

27. Vestbo J, Hurd SS, Agustí AG, Jones PW, Vogelmeier C, Anzueto A, Barnes PJ, Fabbri LM, Martinez FJ, Nishimura M, Stockley RA, Sin DD, Rodriguez-Roisin R. Global strategy for the diagnosis, management, and prevention of chronic obstructive pulmonary disease: GOLD executive summary. Am J Respir Crit Care Med 2013;187:347-65.

28. Zerah-Lancner F, Lofaso F, Coste A, Ricolfi F, Goldenberg F, Harf A. Pulmonary function in obese snorers with or without sleep apnea syndrome. Am J Respir Crit Care Med 1997;156:522-7.

29. Oztürk L, Metin G, Cuhadaroğlu C, Utkusavaş A, Tutluoğlu B. FEF(2575)/FVC measurements and extrathoracic airway obstruction in obstructive sleep apnea patients. Sleep Breath 2005;9:33-8.

30. Calik-Kutukcu E, Savci S, Saglam M, Vardar-Yagli N, Inal-Ince D, Arikan H, Aribas Z, Ozer O, Bosnak-Guclu M, Coplu L. A comparison of muscle strength and endurance, exercise capacity, fatigue perception and quality of life in patients with chronic obstructive pulmonary 
disease and healthy subjects: a cross-sectional study. BMC Pulm Med 2014; $14: 6$

31. Donaldson AV, Maddocks M, Martolini D, Polkey MI, Man WD. Muscle function in COPD: a complex interplay. Int J Chron Obstruct Pulmon Dis 2012;7:523-35.

32. Gosselink R, Troosters T, Decramer M. Distribution of muscle weakness in patients with stable chronic obstructive pulmonary disease. J Cardiopulm Rehabil 2000;20:353-60.

33. Man WD, Soliman MG, Nikoletou D, Harris ML, Rafferty GF, Mustfa N, Polkey MI, Moxham J. Non-volitional assessment of skeletal muscle strength in patients with chronic obstructive pulmonary disease. Thorax 2003;58:665-9.

34. Carvalho TMDCS, Soares AF, Climaco DCS, Secundo IV, Lima AMJ. Correlation of lung function and respiratory muscle strength with functional exercise capacity in obese individuals with obstructive sleep apnea syndrome. J Bras Pneumol 2018;44:279-84.

35. Przybylowski T, Bielicki P, Kumor M, Hildebrand K, MaskeyWarzechowska M, Korczynski P, Chazan R. Exercise capacity in patients with obstructive sleep apnea syndrome. J Physiol Pharmacol 2007;58(Suppl 5):563-74.

36. Vardar-Yagli N, Saglam M, Savci S, Inal-Ince D, Calik-Kutukcu E, Arikan H, Coplu L. Impact of sleep quality on functional capacity, peripheral muscle strength and quality of life in patients with chronic obstructive pulmonary disease. Expert Rev Respir Med 2015;9:233-9.

37. Ali Zohal M, Yazdi Z, Kazemifar AM. Daytime sleepiness and quality of sleep in patients with COPD compared to control group. Glob J Health Sci 2013;5:150-5.

38. Akinci B, Aslan GK, Kiyan E. Sleep quality and quality of life in patients with moderate to very severe chronic obstructive pulmonary disease. Clin Respir J 2018;12:1739-46.

39. Lusic Kalcina L, Valic M, Pecotic R, Pavlinac Dodig I, Dogas Z. Good and poor sleepers among OSA patients: sleep quality and overnight polysomnography findings. Neurol Sci 2017;38:1299-306. 